\title{
Analysis of caesarean sections according to Robson's ten group classification system at a tertiary care teaching hospital in South India
}

\author{
Sneha Badwe Dhodapkar ${ }^{1 *}$, Sindhu Bhairavi ${ }^{1}$, Mary Daniel ${ }^{1}$, \\ Neelima Singh Chauhan ${ }^{1}$, Ramesh Chand Chauhan ${ }^{2}$
}

\footnotetext{
${ }^{1}$ Department of Obstetrics \& Gynecology, Pondicherry Institute of Medical Sciences, Puducherry, India

${ }^{2}$ Department of Community Medicine, Pondicherry Institute of Medical Sciences, Puducherry, India
}

Received: 03 April 2015

Accepted: 09 May 2015

\section{*Correspondence:}

Dr. Sneha Badwe Dhodapkar,

E-mail: snehadhodapkar@gmail.com

Copyright: (c) the author(s), publisher and licensee Medip Academy. This is an open-access article distributed under the terms of the Creative Commons Attribution Non-Commercial License, which permits unrestricted non-commercial use, distribution, and reproduction in any medium, provided the original work is properly cited.

\begin{abstract}
Background: The caesarean section (CS) delivery rate is steadily increasing worldwide, including India. Identifying the proportion of women in various categories as per Robson's ten group classification system and CS rate among them is important to bring down the increasing CS rate.

Methods: This retrospective study was conducted at Pondicherry Institute of Medical Sciences (PIMS), a tertiary care teaching hospital in Puducherry, South India. The data was collected for the women delivered by CS during January 2011 to December 2011 and proportions in various groups as per Robson's ten-group classification system were calculated.

Results: Among a total of 1123 women delivered during study period, 367 (32.6\%) delivered by CS. The CS rates among various groups varied from $100 \%$ among women with breach presentation (group 6 and group 7) and abnormal lies (group 9) to 5.9\% among multiparous women with spontaneous labour having single cephalic pregnancy (group 3). Among women with precious section, CS rate was very high (89.6\%). Women with previous CS (group 5) contributed maximum (40.1\%) to the total number of CS.

Conclusions: In the present study, all women with breech presentation and abnormal lies delivered by CS and repeat CS was the highest contributor to all CS deliveries.
\end{abstract}

Keywords: Robson's ten group classification, Cesarean section

\section{INTRODUCTION}

The Caesarean Section (CS) delivery rate in the India has steadily increased over last 20 years. According to an Indian Council of Medical Research (ICMR) task force study, the CS rate has increased to $28.1 \%$ in $2005-06$, that was $21.8 \%$ in $1993-94 .^{1,2}$ World Health Organization has recommended that Caesarean Section (CS) rates should not be more than $15 \%$, as CS rates above this are not associated with additional reduction in maternal and neonatal mortality and morbidity.,
The reason for the increase in caesarean births are variable including use of electronic fetal monitoring during labor, increasing number of pregnancies following infertility treatment including the multifetal pregnancy, increasing incidence of elderly gravida, increasing number of women with prior caesarean delivery, changes in obstetric training regarding the use of instruments and medico legal concerns etc. The rates vary from one hospital to other and one country to other. Analyzing CS rates in different hospitals and resulting potential reasons of these, can provide important insights into this problem. 
For this an appropriate classification to identify the groups of women undergoing CS and investigation of the underlying reasons for trends is essential so that appropriate effective measures to reduce CS rates can be implemented.

A systematic review of classifications for caesarean section in 2011 suggested that a women-based classifications in general and Robson's classification in particular is best for auditing, analyzing and comparing CS rates across different settings and this helps to create and implement effective strategies specifically targeted to optimize CS rates wherever necessary. ${ }^{5}$

The Robson ten-group classification system ${ }^{6}$ allows analysis of CS rates according to following characteristics of pregnancy.

i. Single or multiple pregnancy.

ii. Nulliparous, multiparous, or multiparous with a previous CS.

iii. Cephalic, breech presentation or other malpresentation.

iv. Spontaneous or induced labor.

v. Term or preterm births.

The present study was conducted to find out the frequency and indications for CS in our setup and to analyze them according to Robson' ten group classification. This would be helping in adopting suitable measures to reduce the CS rate and identifying various challenges in our setting.

\section{METHODS}

This retrospective study was conducted at Pondicherry Institute of Medical Sciences (PIMS), a tertiary care teaching hospital in Puducherry, South India. The study protocol was approved by the Institute Ethics Committee of PIMS.

All the women delivered during a period of one year from January 2011 to December 2011 were included in the study.

Data collection and analysis: The data was collected from the records available in the hospital. A semi-structured questionnaire was used to collect all relevant obstetric information (parity, mode of previous deliveries, previous CS and indications, gestational age, onset of labor, spontaneous or induced labor). All the data was entered in the Microsoft excel spreadsheet 2010 and was analyzed by using SPSS version 16.0 software. Among the women delivered by CS proportions in various groups according to Robson's ten group classification were calculated.

\section{RESULTS}

A total of 1123 women delivered during the study period. Among them, according to Robson's 10-groups classification system, most of the women $374(33.3 \%)$ were in group 1 followed by $222(19.7 \%)$ women in group 3. In group 2 and 4 there were 155 (13.8\%) and 74 $(6.5 \%)$ women respectively whereas group 5 was constituted by 164 (14.6\%) women with previous LSCS. Of all the women with breech presentations $20(1.7 \%)$ were in group 6 that is nulliparous and $10(0.8 \%)$ women were multiparous (group 7). There were 17 (1.5\%) women with multiple pregnancy (group 8). The smallest group was group 9 , with only 5 women having abnormal lies. Group 10 included $82(7.3 \%)$ women with singleton pregnancy with cephalic presentation at $<36$ weeks' period of gestation (Table 1).

Table 1: Relative size of each group according to Robson's ten-groups classification system.

\begin{tabular}{|llll|}
\hline $\begin{array}{l}\text { Group } \\
\text { number }\end{array}$ & $\begin{array}{l}\text { Robson's ten-groups } \\
\text { classification }\end{array}$ & \multicolumn{2}{l|}{$\begin{array}{l}\text { Relative size } \\
\text { of each group }\end{array}$} \\
\hline 1 & $\begin{array}{l}\text { Nulliparous, single cephalic, } \\
\text { >37 weeks in spontaneous labor }\end{array}$ & 374 & 33.3 \\
\hline 2 & $\begin{array}{l}\text { Nulliparous, single cephalic, } \\
\text { >37 weeks, induced or CS } \\
\text { before labor }\end{array}$ & 155 & 13.8 \\
\hline 3 & $\begin{array}{l}\text { Multiparous (excluding } \\
\text { previous CS), single cephalic, } \\
\text { >37 weeks in spontaneous labor }\end{array}$ & 222 & 19.7 \\
\hline 4 & $\begin{array}{l}\text { Multiparous (excluding } \\
\text { previous CS), single cephalic, } \\
>37 \text { weeks, induced or CS } \\
\text { before labor }\end{array}$ & 74 & 6.5 \\
\hline 5 & $\begin{array}{l}\text { Previous CS, single cephalic, } \\
\text { >37 weeks }\end{array}$ & 164 & 14.6 \\
\hline 6 & All nulliparous breeches & 20 & 1.7 \\
\hline 7 & $\begin{array}{l}\text { All multiparous breeches } \\
\text { (including previous CS) }\end{array}$ & 10 & 0.8 \\
\hline 8 & $\begin{array}{l}\text { All multiple pregnancies } \\
\text { (including previous CS) }\end{array}$ & 17 & 1.5 \\
\hline $\begin{array}{l}\text { All abnormal lies (including } \\
\text { previous CS) }\end{array}$ & $\begin{array}{l}\text { All single cephalic, <36 weeks } \\
\text { (including previous CS) }\end{array}$ & 82 & 0.4 \\
\hline Total & 1123 & 100.0 \\
\hline
\end{tabular}

During the study period a total of 367 women were delivered by CS giving the CS rate of $32.6 \%$.

Among various groups, CS rate was $100 \%$ in women with breech presentation either nulligravida (group 6) or multigravida (group 7) and all women with abnormal lie (group 9), where all the women were taken for CS. Of the remaining groups CS rate was highest in group 5, where $89.6 \%(147 / 164)$ of women with previous CS were taken for CS. In the nulliparous women CS rate was higher 
$33.5 \%(52 / 155)$ in group 2, (those who were induced or taken for CS before labour) as compared to those who went in spontaneous labour $23.5 \%$ (88/374) group 1. In multiparous women also CS rate was lower $5.9 \%$ $(13 / 222)$ in those who went in spontaneous labour (group 3 ) where as it was higher $12.2 \%(9 / 74)$ in those who were induced. Among the women with multiple gestations that is group $8,76.5 \%(13 / 17)$ had CS. In group 10 which included all the women with singleton cephalic fetus at less than 36 weeks period of gestation there were $27 \mathrm{CS}$ out of total 82 women (32.9\%) (Table 2).

Table 2: CS rates among women groups according to Robson's Ten-group classification system.

\begin{tabular}{|c|c|c|c|c|c|}
\hline Group & Robson's ten-groups classification & $\begin{array}{l}\text { Number } \\
\text { of CS }\end{array}$ & $\begin{array}{l}\text { Number } \\
\text { of women } \\
\text { in group }\end{array}$ & $\begin{array}{l}\text { CS rate in } \\
\text { each group } \\
(\%)\end{array}$ & $\begin{array}{l}(\%) \text { Contribution } \\
\text { made by each group } \\
\text { to the overall CS } \\
(n=367)\end{array}$ \\
\hline 1 & $\begin{array}{l}\text { Nulliparous, single cephalic, }>37 \text { weeks in } \\
\text { spontaneous labor }\end{array}$ & 88 & 374 & 23.5 & 24.0 \\
\hline 2 & $\begin{array}{l}\text { Nulliparous, single cephalic, >37 weeks, induced } \\
\text { or CS before labor }\end{array}$ & 52 & 155 & 33.5 & 14.2 \\
\hline 3 & $\begin{array}{l}\text { Multiparous (excluding previous CS), single } \\
\text { cephalic, }>37 \text { weeks in spontaneous labor }\end{array}$ & 13 & 222 & 5.9 & 3.5 \\
\hline 4 & $\begin{array}{l}\text { Multiparous (excluding previous CS), single } \\
\text { cephalic, >37 weeks, induced or CS before labor }\end{array}$ & 9 & 74 & 12.2 & 2.5 \\
\hline 5 & Previous CS, single cephalic, $>37$ weeks & 147 & 164 & 89.6 & 40.1 \\
\hline 6 & All nulliparous breeches & 20 & 20 & 100.0 & 5.4 \\
\hline 7 & All multiparous breeches (including previous CS) & 10 & 10 & 100.0 & 2.7 \\
\hline 8 & All multiple pregnancies (including previous CS) & 13 & 17 & 76.5 & 3.5 \\
\hline 9 & All abnormal lies (including previous CS) & 5 & 5 & 100.0 & 1.4 \\
\hline 10 & $\begin{array}{l}\text { All single cephalic, }<36 \text { weeks (including } \\
\text { previous CS) }\end{array}$ & 27 & 82 & 32.9 & 7.4 \\
\hline
\end{tabular}

On analysing the percentage contribution made by each group to overall CS rate it was observed that maximum $40.1 \%(147 / 367)$ percent of the CS were in group 5 (previous CS group).

This was followed by $24 \%(88 / 367)$ in group 1 . Contribution made by other groups were $14.2 \%(52 / 367)$ by group 2, 3.5\% (13/367) by group 3 and $2.5 \%(9 / 367)$ by group 4 . The percentage contribution made by women with breech presentation was $5.4 \%$ (20/367) in nulliparous breech that is group 6 and $2.7 \%(10 / 367)$ in multiparous breech group 7. Of all the CS done $3.5 \%$ $(13 / 367)$ were women with multiple gestation. The lowest percentage contribution $1.4(5 / 367)$ was by group 9 . Twenty seven $(7.86 \%)$ caesarean sections were in group 10 that is women with cephalic presentation $<36$ weeks. (Table 2).

Group 5 was further analyzed according to the indications of CS. Total cases of previous CS > 37 weeks delivered were 164 out of which 17 had Vaginal Birth After Caesarean (VBAC) \& number of patient with repeat LSCS were 147 . Out of the 147 women with previous CS, $31.2 \%$ (46) had some antenatal complication including gestational diabetes and hypertension. There were $10.8 \%$ (16) women with previous $2 \mathrm{CS}$. Of the remaining women with previous CS $22.4 \%$ (33) were not willing for trial of labor. Cephalo pelvic disproportion and contracted pelvis was the indication for repeat CS in $13.6 \%$ (20) and 5.4(8) women respectively. In $12.2 \%$ (18) women scar tenderness was there and hence they were taken for CS (Table 3).

Table 3: Indication of CS during present pregnancy in women with previous LSCS (Group 5).

\begin{tabular}{|lll|}
\hline Indication & Number & Percentage \\
\hline Antepartum complication & 46 & 31.2 \\
\hline CPD & 20 & 13.6 \\
\hline Contracted pelvis & 8 & 5.4 \\
\hline Fetal distress & 2 & 1.3 \\
\hline Not willing for TOLAC & 33 & 22.4 \\
\hline Previous 2 LSCS & 16 & 10.8 \\
\hline Scar tenderness & 18 & 12.2 \\
\hline Unfavourable cervix & 3 & 2.0 \\
\hline Total & 147 & 100 \\
\hline
\end{tabular}

\section{DISCUSSION}

There has been a lot of concern about increasing CS rates in last few years. ${ }^{6}$ This increase has been a global 
phenomenon affecting both the hospitals in developed and developing countries, only difference from one hospital to another is the timing and rate of the increase. One of the factors preventing a better understanding of this trend and underlying causes is the lack of a standardized internationally-accepted classification system to monitor and compare CS rates in a consistent and action-oriented manner. ${ }^{6}$ A systematic review and critical appraisal of available classifications for CS in 2011showedthat women-based classifications in general, and Robson's Ten-group classification in particular, would be in the best position to fulfill current international and local needs. ${ }^{5}$

Dr. M. Robson proposed the following expected rates based on his experience. ${ }^{7}$ The total number of cesareans and deliveries is the sum of the number of each event in Robson groups 1 to 10 combined.

In our study the CS rate was $32.6 \%$. Similar high rates were observed in study by Patel $\mathrm{RV}^{8}$ around $40 \%$ and $25.7 \%$ by Katke $\mathrm{RD}^{9}$ from various hospitals in India. Similar high rates of $32 \%-38 \%$ were also observed in a study done by Abdel-Aleem $\mathrm{H}^{10}$ in Egypt.

Groups 1 and 2 usually account for 35-40\% of all deliveries; Group 1 should be larger than Group 2. In our study group 1 and 2 accounted for $47.1 \%$ and group 1 was larger than group 2.

Groups 3 and 4 usually account for $30-40 \%$ of women; group 3 should be larger than group 4. In our study $26.2 \%$ women were in group 3 and 4 and group 3 was larger than group 4.

Group 5 should comprise no more than $10 \%$ of women. In our study group 5 comprised of $14.6 \%$ of women. Groups 6 and 7 should include $3-4 \%$ of all women, and group 6 is usually twice the size of group 7. Group 6 and 7 included $2.5 \%$ of all women and group 6 had double the number of women as compared to group 7. Group 8 should include $1.5-2 \%$ of women, unless the site has an IVF program or is a referral centre. In our study group 8 had $1.63 \%$ of women. Group 9 should comprise $0.2-0.6 \%$ of women with a CS rate of $100 \%$. In our study group 9 comprised of $0.47 \%$ of women. Group 10 includes approximately $5 \%$ of women. In our study $7.3 \%$ women were in group 10. This is in accordance with the fact that higher proportions (6-7\%) may be seen at referral centers and facilities with a high risk of preterm delivery.

A CS rate for group 1 less than $10 \%$ is desirable. In our study the CS rate in group 1 was $23.5 \%$ which was in accordance with study done in other parts of India by Shirsath $A^{11}(19.6 \%)$ and Kansara Vijay ${ }^{12}(20.11 \%)$ but was higher than a similar study done in Oman by Tahira Kazmi $^{13}$ (13\%). The CS rate for Group 3 should be 2.5$3 \%$. In our study the CS rate in group 3 was $5.9 \%$ which again was in accordance with the studies by Shirsath $\mathrm{A}^{11}$ $(4.8 \%)$ and Kansara Vijay $^{12}(5.4 \%)$. The CS rate in Group 4 should be below $20 \%$. The CS rate in our study in group 4 was $12.2 \%$. This was slightly higher than that of the study done by Shirsath $\mathrm{A}^{11}(6.6 \%)$. With good perinatal outcomes, a CS rate of $50-60 \%$ in Group 5 is excellent. In our study the CS rate in group 5 was $89.6 \%$ which is in accordance with those observations done by Shirsath $A^{11}(87.2 \%)$. This was lower than the CS rate in study by Kansara Vijay ${ }^{12}(98.3 \%)$. If the CS rate in Group 10 is $15-16 \%$ it suggests a high proportion of women with spontaneous onset of preterm labour. Higher CS rates $(30-40 \%)$ in this Group reflect more women with CS following preterm labour induction or a cesarean delivery without labour. In our study the CS rate in group 10 was $32.9 \%$.

In our study women with previous CS that is group 5 made the highest contribution of $40.1 \%$ to overall CS. This was similar to the observation made in most of the studies across India. According to a study done by Wanjari $\mathrm{SA}^{14}$ in Maharashtra repeat CS accounted for $32.8 \%$ of all CS. Similar results were also obtained by Shirsath $\mathrm{A}^{11}(54.5 \%)$ and Kansara Vijay ${ }^{12}(46.1 \%)$. Similar observation was made in a study done by Abdel Aleem $\mathrm{H}^{10}$ in Egypt where $30 \% \mathrm{CS}$ were repeat CS.

It is thus important that efforts to reduce the overall CS rate should focus on reducing the primary CS rates and also encouraging VBAC in patients with previous LSCS.

\section{Funding: No funding sources}

Conflict of interest: None declared

Ethical approval: The study was approved by the institutional ethics committee (IEC/RC/11/44)

\section{REFERENCES}

1. Kambo I, Bedi N, Dhillon BS, Saxena NC. A critical appraisal of cesarean section rates at teaching hospitals in India. Int $\mathbf{J}$ Gynecol Obstet. 2002;79:151-8.

2. Dhillon BS, Chandhiok N, Bharti S, Bhatia P, Coyaji $\mathrm{KJ}$, Das MC, et al. Vaginal birth after cesarean section (VBAC) versus emergency repeat cesarean section at teaching hospitals in India: an ICMR task force study. Int J Reprod Contracept Obstet Gynecol. 2014;3:592-7.

3. World Health Organization. Appropriate technology for birth. Lancet. 1985;326(8452):436-7.

4. Althabe F, Belizán JM. Caesarean section: the paradox (comment). Lancet. 2006 Oct;368(9546):1472-3.

5. Torloni MR, Betran AP, Souza JP, Widmer M, Allen T, Gulmezoglu M, et al. Classifications for cesarean section: a systematic review. PLoS One. 2011;6:e14566.

6. Robson MS. Classification of caesarean sections. Fetal Matern Med Rev. 2001;12(1):23-39.

7. Robson MS. Can we reduce the caesarean section rate? Best Pract Res Clin Obstet Gynaecol. 2001;15(1):179-94. 
8. Patel RV, Gosalia EV, KJ, Vasa PB, Pandya VM. Indications and trends of caesarean birth delivery in the current practice scenario. Int J Reprod Contracept Obstet Gynecol. 2014;3:575-80.

9. Katke RD, Zarariya AN, Desai PV. LSCS audit in a tertiary care center in Mumbai: to study indications and risk factors in LSCS and it's effect on early perinatal morbidity and mortality rate. Int $\mathrm{J}$ Reprod Contracept Obstet Gynecol. 2014;3:963-8.

10. Abdel-Aleem H, Shaaban OM, Hassanin Al, Ibraheem AA. Analysis of cesarean delivery at Assiut University Hospital using the Ten Group Classification System. Int J Gynaecol Obstet. 2013 Nov;123(2):119-23.

11. Kansara V, Patel S, Aanand N, Muchhadia J, Kagathra B , Patel R. A recent way of evaluation of cesarean birth rate by Robson's 10-group system. J Med Pharmaceut Allied Sci. 2014;01:62-70.
12. Shirsath A, Risbud N. Analysis of cesarean section rate according to Robson's 10-group classification system at a tertiary care hospital. Int J Sci Res. 2014 Jan;3(1):401-2.

13. Kazmi T, Saiseema S, Khan S. Analysis of cesarean section rate according to Robson's 10-group classification. Oman Med J. 2012 Sep;27(5):415-7.

14. Wanjari SA. Rising caesarean section rate: a matter of concern? Int J Reprod Contracept Obstet Gynecol. 2014;3:728-31.

DOI: $10.18203 / 2320-1770 . i j r \operatorname{cog} 20150085$

Cite this article as: Dhodapkar SB, Bhairavi S, Daniel M, Chauhan NS, Chauhan RC. Analysis of caesarean sections according to Robson's ten group classification system at a tertiary care teaching hospital in South India. Int J Reprod Contracept Obstet Gynecol 2015;4:745-9. 